\title{
Researches on Methodologies to Verify Reduced Sensitivities of Venturia inaequalis in Field to Difenoconazole and First Indications of a Survey in Italy
}

\author{
Riccardo Fiaccadori \\ Department of Agricultural Sciences (DIPSA), Bologna University, Bologna, Italy \\ Email: riccardo.fiaccadori@unibo.it
}

How to cite this paper: Fiaccadori, R. (2017) Researches on Methodologies to Verify Reduced Sensitivities of Venturia inaequalis in Field to Difenoconazole and First Indications of a Survey in Italy. American Journal of Plant Sciences, 8, 2056-2068.

https://doi.org/10.4236/ajps.2017.89138

Received: May 24, 2017

Accepted: August 1, 2017

Published: August 4, 2017

Copyright $\odot 2017$ by author and Scientific Research Publishing Inc. This work is licensed under the Creative Commons Attribution International License (CC BY 4.0).

http://creativecommons.org/licenses/by/4.0/

(c) †) Open Access

\begin{abstract}
Resistance of Venturia inaequalis to the first IBS triazoles occurred in the 80's in Italy and other countries. Successively number of applications sensibly decreased and problems of resistance to IBS generally disappeared. In 2010 suspects of resistance to the newer IBS difenoconazole, the actually most used IBS, appeared in several countries. In vitro tests the results confirmed the previous researches: the monoconidia from populations which were poorly controlled showed moderate reduced sensitivity respect to well controlled and wild-types. New in vivo tests were realized with preventive and curative applications on seedlings. No different activity among the three types of populations (poorly, well-controlled and wild-types) was found in preventive applications. On the contrary, in curative applications, wild-types and well controlled populations showed a visible and statistically significant activity respect to the poorly controlled. A survey of sensitivity to difenoconazole was carried out in two Italian apple areas in 2013-2015 and showed the presence of populations resistant to difenoconazole. Probably the cause of the resistance spread was the increase of the number of applications of this IBS in the last years. However the problem appears more complex because nowadays resistance regards about all fungicides and with a higher severity respect previous decades. An increase of virulence of $V$. inaequalis strains appears to be the cause of this situation also for the high presence of cultivars with high or moderate susceptibility to scab. Foreseeable remedies consist in a differentiate and appropriate setting of each chemical groups of fungicides in apple scab control, but in long terms new strategies in apple cultivation should be necessary.
\end{abstract}




\section{Keywords}

Venturia inaequalis, Resistance, IBS, Difenoconazole, Apple-Scab Control

\section{Introduction}

The IBS fungicides constitute a very numerous group to control fungi that attack humans, animals and plants. The first fungicides of this group were introduced since 70' years and improved noticeably crop protection thanks to a wide spectrum of action against diseases, the high curative activity and the absence of phytotoxicity.

In the $80^{\prime}$, fungicides belonging to the subgroup of triazoles (such as fenarimol, bitertanol, penconazole, ethaconazole) were commercialized and had a great interest for Venturia inaequalis control, because they allowed curative applications also four days after the beginning of infections [1] [2]. This biological activity improved apple scab control strategies, permitting fixed schedules from 5 - 6 to 7 - 8 days, or to realize programs based on curative applications [3].

A large number of IBS treatments were often applied on several crops without awareness of resistance but several cases of reduced sensitivity to this pathogen and control occurred. The first regarded the IBS ethirimol on barley powdery mildew [4]; later also triazoles were involved on Venturia inaequalis [5], on Ustilago avenae [6], on Blumeria graminis f. sp. hordei [7], on Cercospora beticola [8] etc.

In the 90's, difenoconazole became the most used IBS fungicide in Italy and in many other Countries, thanks to higher curative activity [9] [10]. It resulted also able to exceed resistance to previous IBS's as fenarimol, myclobutanyl and fenbuconazole [11]. By the late Author, the cause could be the major activity of difenoconazole, instead of a moderate cross-resistance with the other IBS fungicides. It was applied with a low number of curative applications (1 or 2 ), for avoiding resistance problems, and it was sometimes alternated with penconazole.

However, in the last years researches evidenced, in different parts of the word, the decrease of sensitivity of difenconazole [12] [13] [14] and activity [15]; from 2012-2013 also in Italy suspected of reduced activity occurred.

Based on the above considerations, the objectives of the present research were to investigate:

-a more efficient methodology for assaying the reduced sensitivity of $V$. inaequalis populations to difenoconazole, which was also apt for monitorings.

-the presence of sensitivity reduction of $V$. inaequalis to difenoconazole (with probable field resistance) in some apple areas of Italian orchards.

Different methods of analysis were available: the traditional in vitro method based on monoconidial isolates on agar plates amended with fungicide; however, it is very time consuming relating to the slowness of $V$. inaequalis growth and a 
second problem is the facility of contamination by other microorganisms. Another method is based on detecting mutations that can occur in strains and populations with reduced sensitivity of $V$. inaequalis. This approach appears to be very complex because phenotypes with reduced sensitivity to IBS present generally several mutations with different biochemical effect, which can have different impact on activity of each IBS, as demonstrated [16] on Micosphaerella graminicola. Moreover, $V$. inaequalis presents another resistance mechanism based on overexpression of Cyp51 gene [17].

Another methodology, recently advised also by FRAC [18], is based on in vivo tests on apple seedlings.

\section{Materials and Methods}

Two biological methodologies were compared (one in vitro and another in vivo):

\subsection{In Vitro Methodology}

Conidia of each sample were sucked from about 30 scabbed spots of leaves and striked on 2.2\% Bacto agar (DIFCO). After 24 hours single conidia were picked with lancet under dissecting microscope $(70 \times)$ and put on potato dextrose agar (PDA 4\% DIFCO). This agar was added with streptomycin sulphate $(100 \mathrm{mg} / \mathrm{L}$, Fluka), tetracycline (100 mg/L, Sigma) and chloramphenicol (100 mg/L, Sigma). After the development of colonies (about 20-30 after 60 days), the tests were carried out.

In each test, 12 colonies were used for any sample and a plug $4 \mathrm{~mm}$ diameter of each colony was transferred on PDA 4\% amended with difenoconazole (as technical material, PESTANAL), at several concentrations: $0 ; 0.001 ; 0.01 ; 0.1 ; 1$ and $10 \mathrm{mg} / \mathrm{L}$ and added with streptomycin $200 \mathrm{mg} / \mathrm{L}$. The diameter of each colony was measured 21 days after incubation in thermostat at $20^{\circ} \mathrm{C}, 12$ hours of light, and then transformed in $\mathrm{EC}_{50}$ value (fungicide Efficacy Concentration reducing 50\% diameter of colonies) by probits analysis. Two trials for each population were realized. The geometric mean of $\mathrm{EC}_{50}$ values of isolates on each trial permitted to obtain two $\mathrm{EC}_{50}$ values/population based on monoconidial isolates.

\subsection{In Vivo Methodology}

The second method was realized under glasshouse conditions, utilizing apple seedlings (cv Golden) with 5 - 7 formed leaves. In a first time, these seedlings were inoculated with drops containing conidia from leaves of each sample. These inoculations multiplied the conidia available for successive in vivo tests.

Experiments verified the levels of leaf infections and were realized with curative applications (56 or 96 hours after the inoculation time) and preventive ones, realized 24,48 or 72 hours before the inoculation time.

Conidia of infected leaves from field were suspended in sterile water, shacked, filtered, reaching a concentration of conidia of $1 \times 10^{5}-2 \times 10^{5} / \mathrm{mL}$ and maintained in plastic boxes with continuous wetness for 48 hours, at $20^{\circ} \mathrm{C}$. This operation 
permitted to increase (multiply) the conidia of each sample, permitting to realize several trials with subpopulations of the sample.

In all preventive or curative treatments, difenoconazole was used as commercial product (Score 25EC, $0.15 \mathrm{ml} \cdot \mathrm{L}^{-1}$ ) distributing about $3.5 \mathrm{~mL}$ for each plant.

After 21 days of incubation at the above-mentioned temperature, the degree of infection was measured as percentage of scabbed area on each susceptible leave.

Two or more experiments were realized for each population, utilizing different subpopulations (a part of infected leaves obtained by multiplication of conidia from infield leaves) for each test and making the inoculation on 5 - 6 plants for every type of application.

The assays were realized on different types of $V$. inaequalis populations: 1) wild types, from untreated apple trees in uncultivated areas; 2) well controlled ones, from commercial orchards satisfactory treated with IBS fungicides and especially with difenoconazole; 3) poorly controlled, from commercial orchards treated with IBS fungicides which were suspected to poorly control the disease.

In Table 1, it is reported that, for all populations (belonging to the three types), the locations of the orchards and the range of the number of treatments with IBS (especially difenoconazole) used in the three years before sampling.

\subsection{Statistical Analysis.}

In vitro tests, the diameters of monoconidial colonies grown at different fungicide concentrations were elaborated as $\mathrm{EC}_{50}$ values, transformed as logarithms

Table 1. Populations of Venturia inaequalis belonging to the three types, their location and number of IBS applied.*

\begin{tabular}{|c|c|c|c|c|c|c|c|c|}
\hline \multicolumn{3}{|c|}{ Wild-types } & \multicolumn{3}{|c|}{ Well-controlled } & \multicolumn{3}{|c|}{$\begin{array}{l}\text { Reduced control and } \\
\text { suspect to IBS }\end{array}$} \\
\hline $\mathrm{N}^{\circ}$ & Location & $\begin{array}{l}\mathrm{N}^{\circ} \\
\text { IBS }^{*}\end{array}$ & $\mathrm{~N}^{\circ}$ & Location & $\begin{array}{l}\mathrm{N}^{\circ} \\
\text { IBS }^{*}\end{array}$ & $\mathrm{~N}^{\circ}$ & Location & $\begin{array}{c}\mathrm{N}^{\circ} \\
\mathrm{IBS}^{*}\end{array}$ \\
\hline 62 & $\begin{array}{c}\text { Holm of } \\
\text { Po river }(\mathrm{MN})\end{array}$ & 0 & 156 & $\begin{array}{l}\text { Borghi } \\
\text { (FC ) }\end{array}$ & 2 & $17-13$ & Trentino & $3-5$ \\
\hline \multirow[t]{6}{*}{$12-03$} & $\begin{array}{l}\text { Railway Park } \\
\text { (BO) }\end{array}$ & 0 & 602 & $\begin{array}{c}\text { Fosso Ghiaia } \\
\text { (RA) }\end{array}$ & $1-2$ & $25-13$ & Trentino & $4-6$ \\
\hline & & & 98 & Cona (FE) & 2 & $29-13$ & Emilia-R. & $2-7$ \\
\hline & & & 202 & $\begin{array}{l}\text { Codroipo } \\
\text { (UD) }\end{array}$ & $0-2$ & $23-13$ & Trentino & $6-8$ \\
\hline & & & Mix & $\begin{array}{l}\text { Mixture of } \\
\text { populations } \\
\text { from several } \\
\text { apple areas }\end{array}$ & $1-2$ & $31-13$ & Emilia-R. & $6-8$ \\
\hline & & & & & & $116-05$ & Lombardia & $4-5$ \\
\hline & & & & & & $31-15$ & Emilia-R. & $5-8$ \\
\hline
\end{tabular}

${ }^{\circ}{ }^{\circ}$ treatments with IBS (mainly difenoconazole) applied in the three years before sampling. 
and analyzed with nested analysis of variance [Stat.Soft.inc. (2013), STATISTICA (version 12)], P: 0.05.

Results of assays in vivo were compared, expressed as relative (percentage) efficiency of difenoconazole in curative or preventive applications on populations belonging to the three types. The relative efficiency (\%) was transformed with arc sine, and elaborated utilizing the same statistic program.

\section{Results}

Table 1 shows locations and characteristics of populations belonging to the three types mentioned. In Table 2 there are the mean $\mathrm{EC}_{50}$ values of monoconidia of each population and the mean $\mathrm{EC}_{50}$ values of all populations belonging to each type. The highest $\mathrm{EC}_{50}$ values were detected for the five suspected populations. The intensity of this increase, expressed as RF (Resistance Factor) and based on mean $\mathrm{EC}_{50}$ value of wild-types, showed moderate increases, from 6.0 to 12.4 (mean RF: 9.2) of isolates of well controlled populations and an RF from 11.0 to 41.3 (mean RF: 24) for isolates of suspected populations.

In Figure 1, $\mathrm{EC}_{50}$ values of monoconidial isolates grouped in each of the three types of $V$. inaequalis populations were statistically compared. Differences in sensitivity were found between wild-types and well-controlled populations, showing the lowest $\mathrm{EC}_{50}$ values for the wild-types. On the contrary, the $\mathrm{EC}_{50}$ values of well and poorly controlled populations were statistically comparable.

Table 2. $\mathrm{EC}_{50}$ values from diameter of monoconidial isolates belonging to the three types of Venturia inaqualis populations.

\begin{tabular}{|c|c|c|c|c|c|c|}
\hline $\begin{array}{c}\mathrm{N}^{\circ} \\
\text { population }\end{array}$ & $\begin{array}{c}\text { Type of } \\
\text { population }\end{array}$ & $\begin{array}{c}\mathrm{N}^{\circ} \\
\text { monocon. } \\
\text { assayed }\end{array}$ & $\begin{array}{c}\text { Mean } \mathrm{EC}_{50} \\
\text { of monoconidia } \\
\text { of each popul. }\end{array}$ & $\begin{array}{l}\text { Mean } \mathrm{EC}_{50} \\
\text { of each type } \\
\text { of popul. }\end{array}$ & $\mathrm{RF}^{* *}$ & $\mathrm{RF}^{* * *}$ \\
\hline 62 & \multirow{2}{*}{ Wild Type } & 9 & 0.003 & \multirow{2}{*}{0.0075} & \multirow{2}{*}{\multicolumn{2}{|c|}{ Base values }} \\
\hline $12-03$ & & 12 & 0.012 & & & \\
\hline 156 & \multirow{5}{*}{ Well-controlled } & 11 & 0.081 & \multirow{5}{*}{0.069} & 10.8 & \multirow{5}{*}{9.2} \\
\hline 602 & & 10 & 0.045 & & 6.0 & \\
\hline 98 & & 12 & 0.064 & & 8.5 & \\
\hline 202 & & 12 & 0.065 & & 8.6 & \\
\hline $\operatorname{Mix}^{*}$ & & 19 & 0.093 & & 12.4 & \\
\hline $17-13$ & \multirow{5}{*}{$\begin{array}{c}\text { Suspected of } \\
\text { poor-control } \\
\text { by IBS } \\
\text { (difenoconazole) }\end{array}$} & 13 & 0.012 & \multirow{5}{*}{0.18} & 16.0 & \multirow{5}{*}{24} \\
\hline $25-13$ & & 13 & 0.083 & & 11.0 & \\
\hline $29-13$ & & 13 & 0.23 & & 30.6 & \\
\hline $23-13$ & & 12 & 0.28 & & 37.3 & \\
\hline $31-13$ & & 13 & 0.31 & & 41.3 & \\
\hline
\end{tabular}

*Populations well controlled by IBS from several Italian apple areas; ${ }^{*}$ Resistance Factor: EC $_{50}$ each population/mean $\mathrm{EC}_{50}$ wild-types; ${ }^{* * *}$ Resistance Factor: mean $\mathrm{EC}_{50}$ value of each type of population/mean $\mathrm{EC}_{50}$ wild-types; ${ }^{* * *} \mathrm{EC}_{50}$ value: probit analysis from diameter $(\mathrm{mm})$ of each monoconidial colony 22 days after the putting on agar. 


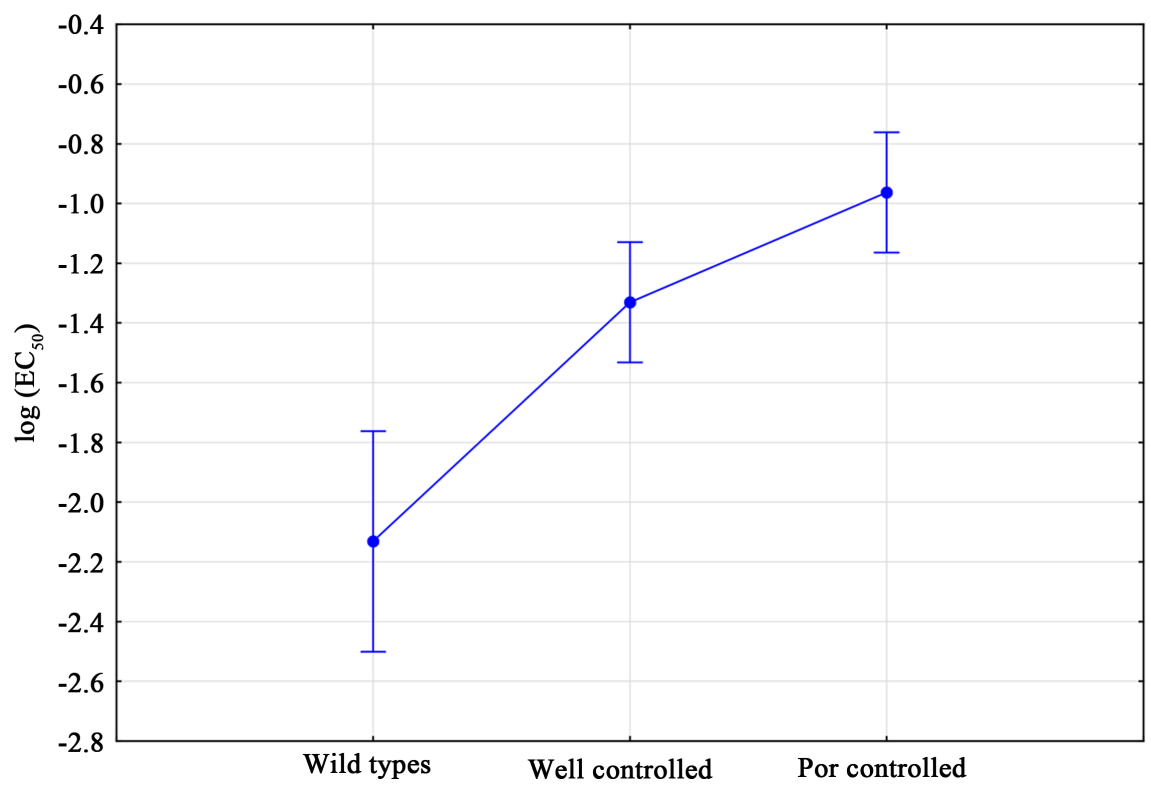

Figure 1. Elaboration of $\mathrm{EC}_{50}$ values of monoconidial colonies in three types of Venturia inequalis populations.

The activity of difenoconazole in in vivo assays on $V$. inaequalis populations is showed in Table 3. Assays were realized on the two wild-type populations, three well controlled and four suspected of reduced control by difenoconazole, generally the same populations tested for monoconidial isolates, no wild-types, both in preventive applications, 24 and 72 hours before inoculation, and in curative ones, 56 and 96 hours after the inoculation.

The population n. 156 was well controlled by difenoconazole that showed a preventive activity (relative efficiency) of $98.5 \%$ ( 48 hours) and 100\% (24 hours). Curative trials revealed an activity from $95.5 \%$ to $100 \%$ in treatments 56 hours after inoculation.

Another well-controlled population, n.98, showed an activity of $96 \%$ in preventive application 72 hours before treatment and $94 \%$ and $100 \%$ in applications 24 hours before. Curative applications showed an efficiency of $100 \%$ and $98.4 \%$ in treatments 56 hours after inoculation and $97.2 \%$, treated 96 hours later.

Population defined "mixed" (well-controlled) permitted moderately inferior values of curative activity respect to the previous populations, both at 56 hours ( $74 \%$ and $72 \%$ ) and 96 hours ( $78 \%$ in two trials). On the contrary, the preventive activity of well controlled ones (72, 48 and 24 hours before the inoculations) was superior to $90 \%$ in the applications 72 hours before inoculation, superior to 98.5\% in applications 48 hours before and higher than $94.1 \%$ in treatments 24 hours before.

The populations suspected of reduced control by difenoconazole showed an efficiency, in preventive treatments higher than $96.0 \%, 80.0 \%$ and $88.0 \%$, when the applications were realized, respectively, 24,48 and 72 hours before inoculation. The curative applications (on the last type of population) realized 56 hours after inoculation, that present a higher number of data, respect all other timings 
Table 3. Degree of infection* and (efficiency $\%^{* *}$ ) of difenoconazole with preventive or curative applications on apple seedlings inoculated with different types of Venturia inaequalis populations

\begin{tabular}{|c|c|c|c|c|c|c|c|}
\hline \multirow{2}{*}{$\begin{array}{c}\text { Pop } \\
\text { (number) }\end{array}$} & \multirow{2}{*}{ Type } & \multirow{2}{*}{ Test } & \multicolumn{3}{|c|}{ Preventive applications } & \multicolumn{2}{|c|}{ Curative applications } \\
\hline & & & 72 hours & 48 hours & 24 hours & 56 hours & 96 hours \\
\hline \multirow{3}{*}{$12-03$} & \multirow{5}{*}{ Wild Type } & $20.0^{*}$ & & $0.0^{\star}(100)^{\star \star}$ & $0.0(100)$ & $0.0(100)$ & \\
\hline & & 18.6 & $0.0(100)$ & & & $0.0(100)$ & $0.0(100)$ \\
\hline & & 22.1 & & & $0.0(100)$ & & \\
\hline \multirow{2}{*}{62} & & 50.0 & & & & $0.0(100)$ & $0.8(98.3)$ \\
\hline & & 17.5 & & & & $0.05(99.2)$ & \\
\hline \multirow{2}{*}{156} & & 42.2 & & & $0.0(100)$ & $0.0(100)$ & \\
\hline & & 45.0 & & $0.6(98.5)$ & & $2.0(95.5) \mathrm{x}$ & \\
\hline \multirow{3}{*}{98} & & 19.1 & & & $0.0(100)$ & $0.0(100)$ & \\
\hline & & 42.3 & $1.6(96.0)$ & & $2.4(94.3)$ & $0.6(98.5)$ & $0.8(98.1)$ \\
\hline & & 44.7 & & & & $2.2(95.0)$ & \\
\hline 202 & Well-controlled & 43.6 & & & & $1.4(96.6)$ & \\
\hline \multirow{2}{*}{99} & & 17.5 & & & & $0.4(97.6)$ & \\
\hline & & 18.6 & & & & $2.2(88.2)$ & \\
\hline \multirow{3}{*}{ Mixed } & & 13.3 & & $0.0(100)$ & & $3.05(77.1)$ & \\
\hline & & 35.0 & $0.66(98.1)$ & & & $9.6(74.0)$ & $7.6(78.4)$ \\
\hline & & 35.6 & $3.3(90.7)$ & & & $10.0(72.0)$ & $7.6(78.4)$ \\
\hline \multirow{2}{*}{$23-13$} & & 10.0 & & $0.2(98.0)$ & & $5.5(44.5)$ & \\
\hline & & 13.0 & & $2.6(80.0)$ & & $6.6(48.7)$ & \\
\hline $26-13$ & & 39.4 & & & & $29.7(24.6)$ & \\
\hline $25-13$ & & 67.7 & & & & $29.1(56.9)$ & \\
\hline \multirow{3}{*}{$29-13$} & Suspected & 10.6 & $1.2(88.6 \%)$ & & $0.33(96.9)$ & $2.88(72.9)$ & \\
\hline & of reduced & 6.1 & & & & $3.9(35.5)$ & \\
\hline & control & 14.6 & $0.0(100)$ & & & $11.0(24.9)$ & \\
\hline \multirow[t]{2}{*}{$31-13$} & & 16.1 & & & & $11.1(31.1)$ & \\
\hline & & 20.5 & & & $0.8(95.9)$ & $7.7(62.1)$ & \\
\hline 116 & & 21.6 & & & & $10.8(50.0)$ & \\
\hline $3-15$ & & 21.3 & $0.3(98.4)$ & & & $16.6(22.0)$ & $15.3(27.2)$ \\
\hline
\end{tabular}

${ }^{*}$ Mean percentage of infected area in susceptible leaves; ${ }^{* *}$ mean percentage of scabbed area of susceptible leaves on each treated sample $\times 100$; mean percentage of scabbed area of susceptible leaves on test.

of application, showed 72.9 as efficiency (\%) of pop. n. 29-13, while the efficiency decreased to $56.9 \%$ for pop. n. $25,50.0 \%$ for pop. n. $116,44.5 \%$ and $48.0 \%$, two results referred to pop. n. 23-13. The percentage of efficiency showed low values: $24.9 \%$ and $31.1 \%$ for pop. n. $31-13,24.9 \%$ for n. $26-13$ and $22.2 \%$ related to pop. n. 3-15.

Statistical analysis of these data (Figure 2) showed that activity of difenoconazole on preventive treatments is significantly similar among the three types of populations, while curative treatments, especially those realized 58 hours after 


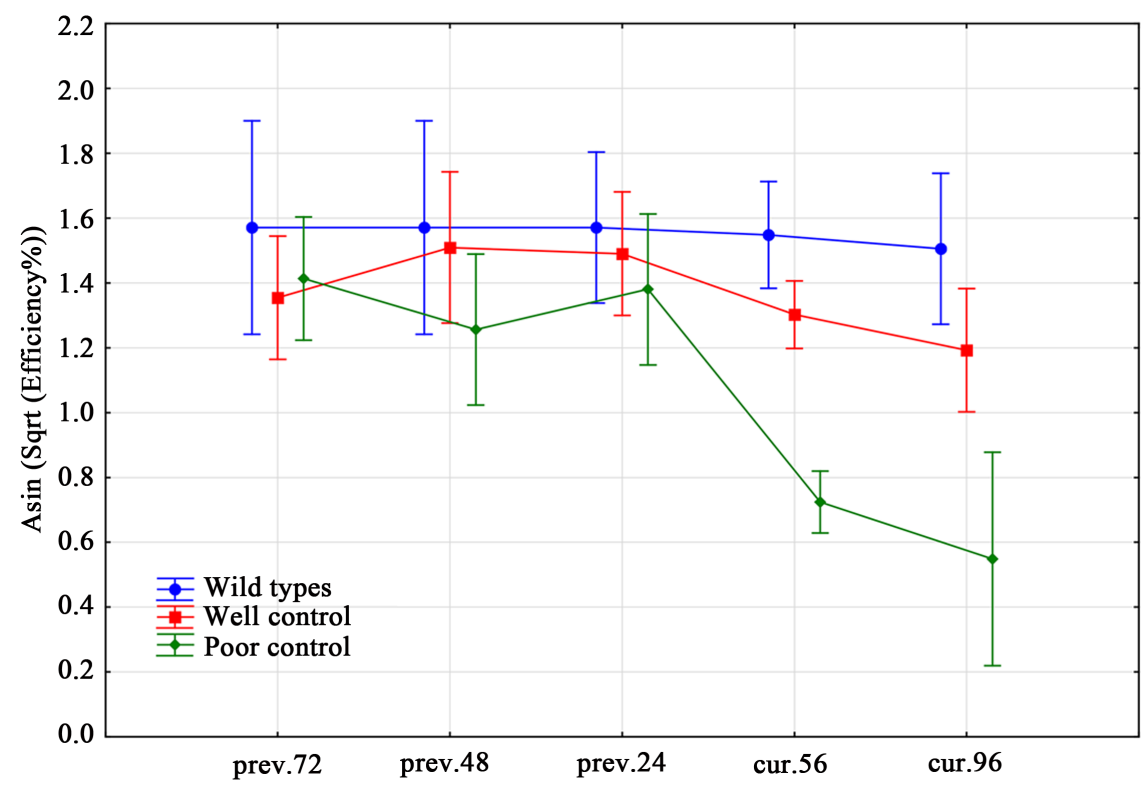

Figure 2. Elaboration of Efficiency (\%) of difenoconazole in preventive and curative applications on three types of Venturia inequalis populations.

application, showed an activity of difenoconazole on "suspected populations" less than that on wild types and "well controlled". Lightly less evident differences were visible in applications 96 hours later that however present a lower number of data.

The populations of $V$. inaequalis belonging to the three types (wild-types, well and poorly-controlled with suspects of resistance to difenoconazole) have been tested with different methods having the aim to verify differences in sensitivity.

\section{Discussion}

The traditional in vitro tests, based on monoconidial isolates grown in media amended with difenoconazole showed rather low differences among the types of populations, as sensitivity (expressed as $\mathrm{EC}_{50}$ values) and as Resistance Factor (RF). With regard to the wild-types, the RF (Resistance Factor) showed a value of 9 related to well-controlled populations and 24 for poorly-controlled ones, which were considered with suspects to have resistance to difenoconazole. This is in line with characteristic of resistance to all IBS fungicides that is due to several mutations, each causing a moderate reduction of sensitivity. Only with several mutations that generally occur in different times, the reduction of sensitivity and activity can increase appreciably [19].

Our in vitro data showed a natural sensitivity to difenoconazole of 0.0075 $\mathrm{mg} / \mathrm{L}$ (mean $\mathrm{EC}_{50}$ of wild-types), and sensitivity reductions until $0.1 \mathrm{mg} / \mathrm{L}$ of populations that do not influence field activity of the fungicide. On the contrary, the sensitivities with higher $\mathrm{EC}_{50}$ values were present in populations with reduced activity and with suspects of resistance to difenoconazole. Other researches, as in Chile [12], found $0.017 \mathrm{mg} / \mathrm{L}$ as mean $\mathrm{EC}_{50}$ of monoconidia of wild-type 
populations, while populations of commercial orchards had a mean $\mathrm{EC}_{50}$ value of $0.08 \mathrm{mg} / \mathrm{L}$, and did not present activity reductions In Serbia wild-types showed a mean $\mathrm{EC}_{50}$ of $0.0175 \mathrm{mg} / \mathrm{L}$, while a population with $0.13 \mathrm{mg} / \mathrm{L}$ as mean $\mathrm{EC}_{50}$ value demonstrated a practical resistance [14]. In USA, Pfeufer [20] proposed a discriminatory dose of $0.125 \mathrm{mg} / \mathrm{L}$ to differentiate sensible from resistant populations to difenoconazole. Stammler (personal communication) reports that a $V$. inaequalis population should be considered resistant when $70 \%$ of isolates present $\mathrm{EC}_{50} \geq 0.3 \mathrm{mg} / \mathrm{L}$.

In conclusion, I think that it could be possible to identify a discriminatory dose of about $0.1 \mathrm{mg} / \mathrm{L}$ and superior values could put in evidence cases of reduced sensitivity and probably activity to difenoconazole.

It is confirmed also that in vitro sensitivity differences among $V$. inaequalis populations, expressed as $\mathrm{EC}_{50}$ values of monoconidia colonies, were generally low. A consequence, evidenced by Franzine [21], is that only with a high number of tested isolates it was possible to evidence clearly statistic differences between populations sensible to IBS and those with reduced sensitivity.

The in vivo method utilized in this work is based on preventive or curative activity of difenoconazole against the three types of $V$. inaequalis populations. It was no possible to show differences among preventive treatments $(24,48$ or 72 hours before inoculation). On the contrary, only curative tests (especially realized about 60 hours after inoculation) showed clearly that the sensitivity and activity of difenoconazole on wild-types and well-controlled populations is significantly higher with respect to the poorly controlled populations. Probably the reason depends on the fact that the curative application acts on spores of a fungus that is already germinated and has developed cells, with enzymes, fatty acids and genetic material (DNA, RNA), with the probability that mutations related to resistance, are becoming expressed.

In the preventive treatments, there are single cells (spores) that are going to germinate with a low presence of molecules that can be devitalized. Must be pointed out that this difference is not treated in scientific publications, even if Sierotsky (Syngenta) confirmed the decrease of activity of curative applications in cases or reduced sensitivity (personal communication).

Also with reference to anilinopyrimidines, the populations of $V$. inaequalis with reduced sensitivity and activity showed this characteristic with curative applications and not with preventive ones [22]. However, the sensitivity and activity differences between sensible and resistant populations were much more evident with difenoconazole respect pyrimethanil and cyprodinil, probably for the intrinsic higher curative activity of the IBS fungicide.

The assessment of the reduced sensitivity to difenoconazole of $V$. inaequalis populations (likely correlated to resistance and reduction of control) is better realized using in vivo tests that are much more less time consuming with respect to in vitro tests and, especially with curative applications, can differentiate more strongly the sensitive from the resistant populations.

About the cause/s that determined an increase of populations resistant to 
difenoconazole, it must be considered what in Italy, and probably in other Countries, several control complains of apple scab occurred, due to the occurrence of QoI fungicides resistance [23]. This situation often caused an interruption in use of QoI and an increase of IBS treatments (mainly difenoconazole), from one-two to four-five-six every year.

This increase of difenoconazole use could be the main cause of resistance. It should be noted that generally disease control problems using difenoconazole appear much less severe in years with low infective pressure of Venturia inaequalis. The particular multigenic nature of resistance in this chemical group could be the cause of this complex and variable behavior, especially for the normal sexual phase from year to year.

Now we are realizing in field and in vivo trials to evaluate how many years of no use of IBS are necessary for a resistant orchard to return in order to re-start using IBS fungicides.

\section{Conclusions}

The demonstrated risk of resistance of $V$. inaequalis to difenoconazole, also in case of a moderate number of applications, contributes to get more complex the employ of fungicides applied in apple scab control in the last years, for occurrence of resistance of Venturia inaequalis, with different characteristics related to each chemical group.

Simpler is the situation of QoI fungicides, because the monosite mode of action can justify the cases of resistance verified with surveys in some areas of North Italy [23] and USA (Michigan) [24]. It is difficult to have a more precise knowledge of diffusion of resistance because few surveys or monitoring were realized by public research organisms.

More complex is the situation of IBS (mainly difenoconazole), dodine, anilinopyrimidines and dithianon. IBS and dodine were introduced several decades ago and showed resistant situations but with a number of applications superior to that occurred in the last years [5] [25].

Anilinopyrimidines seem to be characterized by oligo-sites of action, but even with a moderate number of applications $(4-6)$, showed the possibility of resistance in Italy [22] and France [26]. Notably, these fungicides caused low reductions, not also in sensitivity, but also in scab control (unpublished data).

Dithianon is a multi-site fungicide that was applied, often alone, in all the phases of scab control. Recent researches showed that a high number of applications (more than 8) could cause a reduction of activity (unknown in previous decades) with a moderate degree of infection [27].

All these situations are not endemic but do not seem sporadic. Unfortunately, surveys and monitoring are very few. The most suitable hypothesis of these recent, more severe, resistant problems seems to be a non-sporadic increase of $V$. inaequalis strains with a higher fitness and ability to overcome the mechanisms of activity of fungicides. 
This phenomenon can happen more easily where apple cultivations are present in a large land and there is a diffused presence of cultivars with moderate of high susceptibility to scab. In addition, the persistence of susceptible cultivars is important and indeed Gessler [28] demonstrated a specialization cultivarpathotypes with a progressive increase of virulence of strains on the same cultivar.

Unfortunately, there are not specific researches on the increase of $V$. inaequalis virulence in apple cultivation areas with consequences in scab control, probably because the argument is very challenger, expensive and time consuming.

Therefore, the nowadays setting of apple scab control program is very complex, requires a good knowledge of fungicides and resistance problems and is based on an alternate employ of all chemical groups available for the control of $V$. inaequalis.

Resistance recommendations of FRAC (Fungicide Resistance Action Committee) from main Chemical Companies are important (with possible restriction for QoI fungicides) and must be noted that the use in mixture of fungicides with resistance risk is increasingly advised. It is positive that the new SDHI fungicides do not have any report of resistance also thanks to the general prudence about the number of advised applications (two, consecutive). The knowledge of maximum number of advised applications is important for every chemical group and also the biological activity (preventive and curative performances) of fungicides. The number of curative applications must be very low for all chemical groups, preferring difenoconazole for most critical situations and infections.

However, it must be pointed out that only a much higher diffusion of cultivars with low or very low susceptibility to scab could permit a easier and laid back setting of control programs, but we know that it is a difficult improvement, where not only researchers, but also producers, consumers and relative associations, GDO (Great Distribution Organized), marketing and public government must be involved.

\section{Acknowledgements}

Thanks to G. Battistini and A. Finestrelli for support in realizing trials, E. Muzzi for statistical elaboration, M. Collina for logistic help; to Emilia-Romagna Region and Trentino Province for economic support.

\section{References}

[1] Cesari, A., Minghetti, I. and Gaiba, F. (1979) L'attività "Curativa" ed "Eradicante" di Nuovi Fungicidi Contro le Infezioni Primarie di Venturia inaequalis (Cke) Wint. Informatore Fitopatologico, 3, 25-28.

[2] Schwabe, W.F.S. (1980) Curative Activity of Fungicides against Apple Leaf Infection by Venturia inaequalis. Phytophylactica, 12, 199-207.

[3] Foschi, S., Brunelli, A. and Rapparini, G. (1982) Prove di Lotta Contro la Ticchiolatura e l'Oidio del Melo. Atti Giornate Fitopatologiche, 2, 157-166.

[4] Shepard, M.C., Bent, K.G., Woolner, M. and Cole, A.M. (1975) Sensitivity to Ethirimol of Powdery Mildew from UK Barley Crops. Proceedings of 8 th Insecticide and Fungicide Conference, London, 17-20 November 1975, 59-66. 
[5] Fiaccadori, R., Gielink, A. and Dekker, J. (1987) Sensitivity to Inhibitors of Sterol Biosyntesis in Isolates of Venturia inaequalis from Italian and Dutch Orchards. Netherlands Journal of Plant Pathology, 93, 285-287. https://doi.org/10.1007/BF01998204

[6] Hippe, S. and Koller, W. (1986) Ultrastrutture and Sterol Composition of Laboratory Strains of Ustilago avenae Resistant to Triazole Fungicides. Pesticide Biochemistry Physiology, 26, 209-219. https://doi.org/10.1016/0048-3575(86)90092-1

[7] Buttlers, J., Clarks, J. and Hollomon, D. (1984) Resistance to Inhibitors of Sterol Biosynthesis Inhibiritors in Barley Powdery Mildew. Rijksuniversiteit Faculteit Landbouwwetenschappen Gent, 49, 143-157.

[8] Karaoglanidis, G.S., Ioannidis, P.M. and Thanassoulopoulos, C.C. (2001) Influence of Fungicide Spray Schedules on the Sensitivity of Cercospora beticola to the Sterol Demethylation-Inhibiting Fungicide Flutriafol. Crop Protection, 10, 941-947. https://doi.org/10.1016/S0261-2194(01)00049-7

[9] Danmen, M. and Staub, I. (1992) Protective, Curative and Eradicant Activity of Difenoconazole against Venturia inaequalis, Cercospora beticola and Alternaria solani. Plant Disease, 76, 774-777. https://doi.org/10.1094/PD-76-0774

[10] Battistini, G., Finestrelli A., Brunelli, A. and Fiaccadori, R. (2016) Valutazione Dell'Attività Curativa di Vecchi e Recenti Fungicidi su Venturia inaequalis. Atti Giornate Fitopatologiche, 2, 345-352.

[11] Kunz, S., Deising, H. and Mendgen, K. (1997) Acquisition of Resistance to Sterol Demethylation Inhibitors by Populations of Venturia inaequalis. Phytopathology, 87, 1272-1278. https://doi.org/10.1094/PHYTO.1997.87.12.1272

[12] Henríquez, J.L., Samiento, V. and Alarcón, P. (2011) Sensitivity of Venturia inaequalis Chilean Isolates to Difenoconazole, Fenarimol, Mancozeb, and Pyrimethanil. Chilean Journal of Agricultural Research, 71, 39-44. https://doi.org/10.4067/S0718-58392011000100005

[13] Pfeufer, E. and Ngugi, H.K. (2012) Orchard Factors Associated with Resistance and Cross Resistance to Sterol Demethylation Inhibitor Fungicides in Populations of Venturia inaequalis from Pennsylvania. Phytopathology, 102, 272-282. https://doi.org/10.1094/PHYTO-04-11-0117

[14] Ngugi, H.K. and Pfeufer, E.E. (2011) Resistance to DMI (SI) Fungicides in Populations of Venturia inaequalis, the Apple Scab Pathogen from Pennsylvania Apple Orchards. Pennsylvania Fruit News, 91, 22-27.

[15] Stevic, M., Vulsa, P. and Elezovic, I. (2010) Resistance of Venturia inaequalis to Demethylation Inhibiting (DMI) Fungicides. Žemdirbyste Agriculture, 97, 65-72.

[16] Mehl, A., Krieg, U. and Suty-Heinze, A. (2010) Monitoring Mycosphaerella graminicola: Relevance of in Vitro Testing and Cyp51 Mutations. Rothamsted Experimental Station, Harpenden, 2-14.

[17] Schnabel, G. and Jones, A.L. (2001) The 14a-Demethylase (CYP51A1) Gene Is Overexpressed in Venturia inaequalis Strains Resistant to Myclobutanil. Phytopathology, 91, 102-110. https://doi.org/10.1094/PHYTO.2001.91.1.102

[18] Fungicide Resistance Action Committee (2012) List of Monitoring Methods. www.frac.info/monitoring-methods

[19] Dekker, J. and Georgopoulos, S.G. (1982) Fungicide Resistance in Crop Protection. The Centre for Agriculture and Bioscience International, Wallingford, 177-186.

[20] Pfeufer, E. (2010) Status of Resistance to Sterol-Demethylation Inhibiting Fungicides in Populations of Venturia inaequalis from Pennsylvania Apple Orchards. Pennsylvania University, Philadelphia, 39. 
[21] Franzine, A., Smith, F., Parker, D.M. and Koller, W. (1997) Sensitivity Distribution of Venturia inaequalis to the Sterol Inhibitor Fungicide Flusilazole, Baseline Sensitivity and Implications for Resistance Monitoring. Phytopathology, 81, 392-396.

[22] Fiaccadori, R., Cicognani, E., Collina, M. and Brunelli, A. (2007) Study on the Sensitivity of Venturia inaequalis to Anilinopyrimidine Fungicides in Italy. Communications in Agricultural \& Applied Biological Sciences, 72, 997-1001.

[23] Fiaccadori, R., Collina, M. and Brunelli, A. (2013) Reduced Sensitivity of Venturia inaequalis to Strobilurins and Anilinopyrimidines in Italy. Integrated Protection of Fruit Crops. IOBC-WPRS Bulletin, 91, 345-350.

[24] Lesniak, K.E., Proffer, T.J., Beckerman, J.L. and Sundin, G.W. (2011) Occurrence of QOI Resistance and Detection of the G143A Mutation in Michigan Populations of Venturia inaequalis. Plant Disease, 95, 927-934.

https://doi.org/10.1094/PDIS-12-10-0898

[25] Meszka, B., Broniarek-Niemiec, A. and Bielenin, A. (2008) The Status of Dodine Resistance of Venturia inaequalis Populations in Poland. Research Institute of Pomology and Floriculture, Skierniewice, 57-61.

[26] Micoud, A. and Remuson, F. (2006) La Tavelure du Pommier: Comment Gérer les Resistences. Phytoma-La Défense des Végétaux, 590, 20-23.

[27] Battistini, G., Muzzi, E., Collina, M., Brunelli, A. and Fiacccadori, R. (2015) Meeting on Apple Scab Control in Apple Italian Areas and Presentation of Results on Sensitivity of Venturia inaequalis to Fungicides. Institute of San Michele all'Adige, San Michele all'Adige.

[28] Sierotzki, H., Eggenschwiler, M., Boilat, O., McDermot, J. and Gessler, C. (1994) Detection of Variation in Virulence toward Susceptible Apple Cultivars in Natural Populations of Venturia inaequalis. Phytopathology, 84, 1005-1009. https://doi.org/10.1094/Phyto-84-1005

\section{Scientific Research Publishing}

\section{Submit or recommend next manuscript to SCIRP and we will provide best service for you:}

Accepting pre-submission inquiries through Email, Facebook, LinkedIn, Twitter, etc. A wide selection of journals (inclusive of 9 subjects, more than 200 journals)

Providing 24-hour high-quality service

User-friendly online submission system

Fair and swift peer-review system

Efficient typesetting and proofreading procedure

Display of the result of downloads and visits, as well as the number of cited articles

Maximum dissemination of your research work

Submit your manuscript at: http://papersubmission.scirp.org/

Or contact ajps@scirp.org 